HORTSCIENCE 26(4):410-411. 1991.

\title{
Occurrence and Inheritance of Resistance to Eastern Filbert Blight in 'Gasaway' Hazelnut
}

\author{
Shawn A. Mehlenbacher', Maxine M. Thompson', and \\ H. Ronald Cameron ${ }^{3}$ \\ Oregon State University, Corvallis, OR 97331 \\ Additional index words. Corylus avellana, Anisogramma anomala, filbert, disease \\ resistance, tree breeding
}

\begin{abstract}
Gasaway' hazelnut (Corylus avellana L.) is highly resistant to eastern filbert blight caused by Anisogramma anomala (Peck) E. Muller. Progeny produced from controlled crosses of 'Gasaway' with five susceptible genotypes and open pollination in a 'DuChilly' orchard were planted in a diseased orchard and rated for symptom expression for 9 to 10 years. All progeny were found to segregate 50\% resistant : 50\% susceptible, indicating that 'Gasaway' is heterozygous for a single dominant resistance gene.
\end{abstract}

Eastern filbert blight is a serious disease of hazelnuts (filberts). The disease is endemic to eastern North America, where the American hazel (C. americana Marsh.) serves as its host. It was first reported in the Pacific Northwest near Woodland, Wash., in 1970 (Davidson and Davidson, 1973) and is believed to have been introduced in the early 1960s on stock imported from the East Coast. The disease spread through Clark and Cowlitz counties, Wash., and to two orchards near St. Helens, Ore., in the 1970s (Gottwald and Cameron, 1980b) and was discovered in Damascus, Ore., in 1986. The disease is continuing to spread and is now firmly

Received for publication 24 May 1990. Oregon Agricultural Experiment Station Technical Paper no. 9250. This research was funded by the Oregon Hazelnut Commission. We acknowledge the assistance of personnel at the Southwest Washington Experiment Station. The cost of publishing this paper was defrayed in part by the payment of page charges. Under postal regulations, this paper therefore must be hereby marked advertisement solely to indicate this fact.

'Assistant Professor.

${ }^{2}$ Professor Emeritus, Dept. of Horticulture.

${ }^{3}$ Professor Emeritus, Dept. of Botany and Plant Pathology. established in the northern third of the Willamette Valley, where $98 \%$ of the U.S. hazelnut crop is produced.

The pathogen has a 2-year life cycle, including an incubation period of 13 to 16 months when no symptoms are expressed (Gottwald and Cameron, 1980a). Spores are released and spread by wind-driven rain during fall, winter, and spring. They are thought to enter buds as they swell in response to warm weather in the spring. The disease may also enter young leaves and shoots as they emerge. Symptoms expressed 16 months after infection include sunken cankers that contain rows of raised, ellipsoid stromata along the length of the branch. Infected twigs often die suddenly with leaves attached. Cankers enlarge 30 to $100 \mathrm{~cm}$ annually along the branch. These perennial cankers can exceed $2 \mathrm{~m}$ in length and girdle scaffold limbs and the tree trunk. Most of the canopy of older trees of susceptible cultivars is killed in 7 to 10 years.

Observations of cultivar susceptibility are the result of orchard surveys (J. Pinkerton, personal communication). The pollenizers 'Daviana' and 'Butler'; the cultivars Ennis, DuChilly, and Royal; and the ornamental $C$. avellana var. contorta are highly susceptible to the disease. Oregon's leading cultivar, 
Table 1. Reaction of 'Gasaway' seedlings to eastern filbert blight.

\begin{tabular}{|c|c|c|c|c|c|c|}
\hline \multirow[b]{2}{*}{ Progeny } & \multirow[b]{2}{*}{ Parentage $^{2}$} & \multicolumn{2}{|c|}{ Seedling reaction } & \multirow[b]{2}{*}{$\chi^{2^{y}}$} & \multirow[b]{2}{*}{$\mathrm{df}$} & \multirow[b]{2}{*}{$P$} \\
\hline & & Resistant & Susceptible & & & \\
\hline 76003 & OSU $10-68 \times$ Gasaway & 30 & 36 & 0.55 & 1 & $0.5-0.6$ \\
\hline 76006 & OSU 13-19 x Gasaway & 29 & 20 & 1.65 & 1 & 0.8 \\
\hline 76022 & OSU $20-58 \times$ Gasaway & 7 & 5 & 0.33 & 1 & $0.4-0.5$ \\
\hline 76040 & Montebello x Gasaway & 13 & 16 & 0.31 & 1 & $0.4-0.5$ \\
\hline 76002 & Gasaway o.p. ${ }^{x}$ & $72^{w}$ & 75 & 0.06 & 1 & 0.2 \\
\hline 80049 & Casina $x$ Gasaway & 30 & 33 & 0.14 & 1 & 0.3 \\
\hline Heterogeneity & & & & 2.94 & 4 & $0.4-0.5$ \\
\hline Pooled & & 181 & 185 & 0.04 & 1 & 0.2 \\
\hline
\end{tabular}

2OSU 10-68 is a 'Barcelona' $x$ 'Compton' hybrid, OSU 13-19 a 'Barcelona' $x$ 'Lansing' hybrid, and OSU $20-58$ a 'Tonda Gentile delle Langhe' $x$ 'Bellhusker \#2' hybrid. All six of these cultivars, 'Casina', and selection OSU 13-19 were exposed to eastern filbert blight and found to be susceptible.

${ }^{y}$ Data tested for goodness-of-fit to a 1:1 ratio.

'Open-pollinated seeds collected from 'Gasaway' trees in a 'DuChilly' orchard.

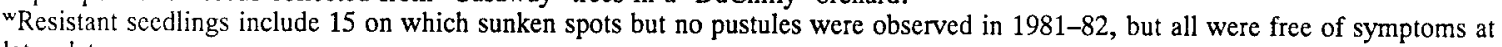
later dates.

'Barcelona', and the pollenizer 'Hall's Giant' are considered tolerant, as infected trees remain productive for longer periods. In 1975, it was noted that 40-year-old trees of the pollenizer 'Gasaway' were totally free of symptoms, while the surrounding 'DuChilly' trees were heavily infected (Cameron, 1976). No symptoms have been observed in subsequent years of observation in infected orchards.

The parentage of 'Gasaway' is unknown. It originated in Battle Ground, Wash., in the orchard of Richard Gasaway (O. Jemtegaard, personal communication) and was selected and propagated as a late-shedding pollenizer for 'DuChilly'. It was introduced by Carroll D. Bush Nurseries in Barton, Ore., in 1926 (Lagerstedt, 1975).

Resistance to eastern filbert blight and late pollen shedding are among the very few redeeming qualities of 'Gasaway'. Trees are vigorous but produce low yields of small, long nuts of poor quality. Nuts are generally borne in pairs in husks half as long as the nuts. The nuts average $1.5 \mathrm{~g}$ and are $47 \%$ kernel by weight. Shells are dull gray. Kernels have abundant fiber on the pellicle, and the pellicle is not removed by blanching (Mehlenbacher and Smith, 1988). Kernel flavor has been rated as poor. Nuts show a low percentage of defects, most of which are blanks (shells lacking kernels).

In 1976, four susceptible genotypes were used as female parents in crosses with 'Gasaway'. Seeds were also harvested from 'Gasaway' pollenizer trees in a 'DuChilly' orchard. Seeds were germinated and seed- lings planted in an infected orchard in Nov. 1977. One year later, the seedlings were relocated to the Southwest Washington Experiment Station, Vancouver. Seedlings were rated for presence of stromata during Winters 1981-82 through 1986-87. Seedlings on which stromata were observed were classified as susceptible. A few seedlings exhibited small, sunken areas when observed in 1981-82. These cankers never developed stromata, and the seedlings were vigorous and symptomless in subsequent years. These seedlings were classified as resistant. An additional cross, 'Casina' $\times$ 'Gasaway', was made in 1980, and seedlings were planted in the Vancouver plot in Fall 1981. These seedlings were rated for disease expression in 1984-85, Apr. 1988, and Aug. 1989. All progenies exhibited a 1:1 ratio for resistance and susceptibility (Table 1), indicating that resistance is conferred by a single dominant gene for which 'Gasaway' is heterozygous.

The resistance of 'Gasaway' appears to be different from that of the American hazel, although the degree of resistance present in the latter species remains unclear. Fuller (1910) attributed survival of the species to the replacement of infected shoots with new shoots from the roots. Weschcke (1954), however, noted that the American hazel quickly walls off infected areas. Corylus americana $\times C$. avellana hybrids usually retain some of the resistance of the wild parent (Slate, 1963; Weschcke, 1954), and the percentage of highly resistant seedings is low (Weschcke, 1970). Resistance in this species appears to be variable and under the control of many genes, which is quite different from our observations of 'Gasaway' and its progeny.

\section{Literature Cited}

Cameron, H.R. 1976. Eastern filbert blight established in the Pacific Northwest. Plant Dis. Rptr. 60:737-740.

Davidson, A.D. and R.M. Davidson, Jr. 1973. Apioprothe and Monochaetia cankers reported in western Washington. Plant Dis. Rptr. 57:522523

Fuller, A.S. 1910. Filbert or hazelnut, p. 118146. In: The nut culturist. Orange Judd, New York.

Gottwald, T.R. and H.R. Cameron. 1980a. Infection site, infection period, and latent period of canker caused by Anisogramma anomala in European filbert. Phytopathology 70:1083-1087.

Gottwald, T.R. and H.R. Cameron. 1980b. Disease increase and the dynamics of spread of canker caused by Anisogramma anomala in European filbert in the Pacific Northwest. Phytopathology 70:1087-1092.

Lagerstedt, H.B. 1975. Filberts, p. 456-489. In: J. Janick and J.N. Moore (eds.). Advances in fruit breeding. Purdue Univ. Press, West Lafayette, Ind

Mehlenbacher, S.A. and D.C. Smith. 1988. Heritability of ease of hazelnut pellicle removal. HortScience 23:1053-1054.

Slate, G.L. 1963. The present status of filbert breeding. Ann. Rpt. Northern Nut Growers Assn. 52:24-26.

Weschcke, C. 1954. Growing nuts in the north. Webb. St. Paul.

Weschcke, C. 1970. A little nut history. Proc. Northern Nut Growers Assn. 61:113-116. 